\title{
Organizational Climate and Oil Companies. Multidimensional Study with Workers from the Drilling Department in Tabasco, Mexico
}

\author{
Carlos de Jesús González López \\ Universidad Juárez Autónoma de Tabasco (México) \\ María Del Carmen Sandoval Caraveo \\ Universidad Juárez Autónoma de Tabasco (México) \\ Edith Georgina Surdez Pérez \\ Universidad Juárez Autónoma de Tabasco (México)
}

\begin{abstract}
The organizational climate is the perception of workers in a company about the processes of the organization and the relationships among its members. The aim of this study was to conduct a study of organizational climate to employees working in an oil company located in Tabasco, Mexico. The research is descriptive and correlational. The design is non-experimental with a quantitative approach. A questionnaire with a Likert scale and reliability of 0.838 in the Cronbach Alpha coefficient was used. The dimensions of organizational climate were autonomy, cohesion, support, work pressure and innovation. The ANOVA analysis of variance reported a statistically significant difference between cohesion and employment status; autonomy and work area. The Pearson correlation indicated a weak correlation between the category of worker and the dimension of autonomy. In conclusion, the results indicate a favorable trend toward organizational climate.
\end{abstract}

Keywords: Organizational climate, cohesion, work pressure, oil workers, drilling.

\section{INTRODUCTION}

At present, the diversity of organizations that exist in Mexico need to face new and greater challenges in order to be competitive in the field to be developed; given this reality, the human capital of each organization becomes a fundamental pillar for the achievement of its objectives.

Every organization has a work environment that is perceived and experienced by the members thereof, and considers the feel and react of each individual. This environment somehow affects the performance of employees in the organization; the relationship between the worker and his environment can provide satisfactory results, or conversely, can cause problems not only in the performance of his work, but also personally. In this sense, Werther, Davis and Guzmán (2014) argue that the deterioration of the work environment causes staff to lose enthusiasm for their work, and this is reflected not only in higher levels of absenteeism and turnover rates, but also in the slowness, reluctance and indifference that characterize the sclerotic institutions; the staff start to psychologically drift apart from their work and dedicate to meet the minimum required. 
In this regard, Chiavenato (2011) indicates that the organizational climate is closely related to the motivation of its members; when it is high, the organizational climate increases and results in

\section{CORRESPONDING AUTHOR}

satisfying relationships, encouragement, interest, collaboration, etc., on the contrary, when motivation is low among the members, either due to frustration or barriers to satisfy needs, the organizational climate tends to decrease and is characterized by depression states, indifference, apathy, dissatisfaction, and so on. The author adds that in extreme cases, it occurs due to states of aggression and dissatisfaction that are common in the frontal clashes with the organization such as strikes or demonstrations.

The problems of people have been the most difficult to resolve, and also those that absorb the most time to administrators. In order to address these problems, it is recommended that administrators understand the perceptions of employees regarding different aspects of the organization. Besides, they must know as much as they can about the factors that significantly influence the behavior of people in their organization. One of these factors is the organizational climate, that is, the psychological atmosphere of all departments in an organization (Furnham, 2001).

Werther and Davis (2008) associate the organizational climate with quality of life at work when they say that this quality is achieved "by improving the work environment, creating a favorable working environment to the company, and at the same time conducive to sustainable, healthy and comprehensive development of the productive life of the workers "(p. 427). Similarly, Davis and Newstrom (2003) mention that the term quality of life at work refers to the favorable or unfavorable nature of the working environment in its entirety for people, and also that companies recognize their responsibility to create jobs and excellent working conditions for individuals and for the economic welfare of the organization.

The quality of the work environment is determined by the way the staff judge their own activity in the organization, although humans produce variable results when they decide to provide services. Studies on the subject over the past two decades reveal two important aspects: 1) in order to increase productivity, it is essential to improve the quality of the working environment and 2) most people think that they enjoy a high-level working environment when they contribute to the success of the company in any significant way (Wether, Davis and Guzmán 2014). In this way, "both leaders of the company and professionals in human capital management must unite to create an organizational climate in which people are treated as such and as experts responsible for their posts" (Wether, et al. 2014, p. 309).

When talking about organizational climate, Brunet (2011) points out that in these times, it is very important for organizations to identify, meet and consider the elements governing the working environment of its members in their work area and throughout the organization. He also mentions that at the present time, it is necessary to understand the factors that influence the performance of individuals at work.

Organizational climate studies are relevant for organizations, since managers need to have accurate and timely information in order to develop strategies that allow them to involve and engage employees from their organization in the enhancement of organizational processes, as well as in their individual productivity, which results in the increase of the competitiveness of the company. 
The purpose of this research was to determine the perception of organizational climate of employees working in the drilling department in a company dedicated to the exploration, distribution and commercialization of crude and refined oil in Tabasco, Mexico. It was created in response to the problem of staff absenteeism that the company is facing in this area. If these absences are not covered on time, there is a risk that the activities could be suspended, and thus a decrease in oil production and important economic losses. Given this situation, it is necessary to determine the existence of a favorable or unfavorable organizational climate for the activities of this organization. It is important to note that no history of previous studies of organizational climate in Mexican oil companies was found in the literature consulted, so this research can be considered a pioneer in this type of institution.

\section{THE ORGANIZATIONAL CLIMATE}

\section{Origin of the construct}

The concept of organizational climate is rooted in the thirties. It emerged with the Hawthorne studies at Western Electric and the current of human relationships that capitalizes the discovery of the socio-emotional dimension of the organization, relates it to the notion of leadership and associates it with the organization conceived as structure (Fernández, 2004). In this vein, Lewin (1951); Lewin, Lippit and White (1939, quoted by Salgado, Remeseiro and Iglesias, 1996) point out that the development of the concept of social climate and its research began in the early thirties with the research conducted by Lewin and his associates; it is the Lewin's work $(1935,1939,1951)$ which serves as a stimulus for the development of interest in the social context, his experimental laboratory work with Lippit and White on group leadership styles, introduces the term 'climate' as a link between the person and the environment, the group will behave differently depending on the behaviors of the leaders, creating thus different climates (Silva, 1992).

On the other hand, Mújica de González (2007) indicates that the term organizational climate was raised from the sixties with the emergence of organizational behavior, organizational development and the theory of systems applied to the study of the organizations, and adds that the analysis of the organizational climate consists of a set of factors expressed in terms of components, dimensions, categories and variables that enable its study, according to research purposes.

Brunet (2011) states that the concept of organizational climate is recent and was first introduced in industrial/organizational psychology by Gellerman in 1960, and that the theoretical origins are not always clear in the research; he also mentions that the concept of climate is made up of two schools of thought, Gestalt's school and the functionalist school; the first one takes the position through which individuals understand the world around them based on perceived and inferred criteria, and that these behave according to how they see the world, so that the perception of the working environment or the environment itself is what influences the behavior of an employee. The functionalist school states that the thinking and behavior of an individual depend on the environment around them, and individual differences play an important role in the individual's adaptation to his environment, so that an employee interacts with his environment and participates in the determination of this climate.

\section{Concept}

The organizational climate has been conceptualized by different authors, such as Alves (2000) who defines it as the result of the perception that workers have about an objective reality that is the organization; what workers live and feel for a particular organization. Furnham (2001) claims that the organizational climate can be considered a descriptor of organizational 
attributes, expressed in terms that characterize individual experiences with the organization. For Sandoval (2004, p. 84), the organizational climate "is the work environment perceived by members of the organization and includes a structure, a style of leadership, communication, motivation and rewards, which all directly influence the behavior and performance of individuals."

Downey, Hellriegel, Phelps and Slocum (1974) state that the organizational climate is a set of attributes that can be perceived by the individual about a particular organization or their components, and may be induced by the way the organization and/or its components deal with its members and their environment.

Chiavenato (2011) expresses that the organizational climate is the internal environment among the members of the organization and that it is closely related to their motivation, he also adds that it refers to the motivational properties of the organizational environment, as well as the aspects of the organization that lead to stimulation of different types of motivations in their members, and the organizational climate is favorable when it boots morale and meets the personal needs of the members; and it is unfavorable when it frustrates those needs. Mújica de Gónzalez (2007) perceives the organizational climate as a set of shared perceptions that people gain about the reality of work in the organization, where social components (policies, rules, regulations, role playing, operation of groups and structurals) combine.

The definitions of organizational climate refer to the way how people perceive the surrounding environment of the organizations in which they interact (Castillo, Lengua and Pérez, 2011; Segredo and Díaz, 2011; Mújica de González, 2007; Watkin and Hubbard, 2003; Sandoval, 2004; Alves, 2000; Brunet, 2011; Downey, et al 1974) these perceptions are related to external and internal factors that are found within the personal and institutional dimensions of the company, which are considered within the strategic importance for the organizations, perceived as a fortress in quality processes and continuous improvement (Segredo, et al. 2011).

Martín (2000) argues that the working environment in organizations is a facilitator, as well as a result of numerous interactions and organizational processes including planning with all its instruments and components, considering the human element, communication, participation, trust and respect. In this regard, Alves (2000, p. 124) states that "A high level of communication, mutual respect, feelings of belonging, friendly atmosphere, mutual acceptance and encouragement, along with a general feeling of satisfaction are some of the factors that lead straight to a favorable climate, proper productivity and good performance."

The organizational climate has been associated in various studies with variables such as job satisfaction (Downey et al 1974. Salgado et al 1996; Robles, et al 2005; Chiang, Salazar and Núñez, 2007; Chiang, Salazar, Huerta and Núñez, 2008) leadership (Alves, 2000; Gonzalez Parra, 2008; Contreras, et al 2009) the culture of the organization (Méndez Hernández and Vargas, 2013, González et al, 2008) with the quality of service and quality of life at work (Bernal, Pedraza and Sánchez, 2015; Casas, Repullo, Lorenzo and Cañas, 2002). Studies have reported that organizational climate is a variable that relates to other variables interacting in the context of the organization.

\section{Type and design of the research}

\section{METHODOLOGY}

The research was descriptive and correlational, due to the fact that the aim of this study was not to modify the study variables, but only seek to determine the perception of workers in the 
oil company regarding their work environment, as well as establish the relationship between the dimensions of organizational climate with sociodemographic variables. The ANOVA analysis of variance was used in order to determine the existence of statistically significant differences between the organizational climate and the variables of employment status, work area, marital status, age, category at work and seniority in their current category.

The design is transversal with quantitative approach. This study is not experimental because the research was conducted in the natural context where workers perform their working hours, that is, they were not exposed to different conditions than those in which they perform their work.

\section{Population and sample}

The population is made up of 198 workers; a simple random sampling method with a 95\% confidence and 5\% error level (Walpole, Myers, Myers and Ye, 2007) was used. The sample consisted of 131 subjects, though it was only possible to apply the instrument to 120 workers due to some restrictions on the access to the drilling department.

In respect of gender, all the workers are men; with regard to marital status, 105 are married and 15 are single; in terms of age, 12 are reported to be under the age of 30; 43 are between 31 and 40; 43 are between 41 and 50; and 22 are older than 50 years old. Regarding the work area to which they belong, 89 of them mentioned to be in operation and 31 in maintenance. Concerning the category they hold in the company, the results showed that one of them is a technical drilling inspector, 12 are drillers, 14 are drilling assistants (on supervision and other activities), 16 are drilling assistants (on maneuvers in heights), 32 are drilling assistants (on maneuvers on the floor), 7 are operators of auxiliary equipment, 9 are assistants on drilling works, 4 are in charge of technical maintenance "A", 4 are in charge of mechanical maintenance, 5 are in charge of electrical maintenance, 3 are in charge of welding maintenance, 3 are assistants in mechanical maintenance, 5 are assistants in electrical maintenance, and 5 are assistants in welding maintenance. Regarding the time they have worked in this category, 27 indicated that between one and three years, 52 between three and six years, 17 between six and nine years, 11 between nine and 12 years and 13 over 12 years old.

In relation to the situation regarding their employment contract, 33 said they are stable workers, 46 said they are in promotion to a higher level post and 41 said they are in a transitional post. Concerning the time they have worked in drilling, 2 workers said they have worked for less than a year, 23 between 1 and 5 years, 47 between 5 and 10 years, 23 between 10 and 15 years and 25 over 15 years.

\section{Research instrument}

To conduct this study, an adaptation of the questionnaire of organizational climate by Chiang, et al. (2008) was made. The first part of the instrument was in relation to sociodemographic variables; five of them were included in relation to the organization: work area, category (post), time working in that category, employment status (stable, in promotion or transitional) and seniority; two sociodemographic variables regarding the individual were added: age and marital status.

The second part of the questionnaire measured the organizational climate through 5 dimensions (Table 1). It was structured in a Likert scale with five response options where $1=$ strongly disagree, 2 = disagree, 3 = neither agree nor disagree, $4=$ agree, $5=$ strongly agree. In 
this way, to agree and strongly agree represent a favorable climate; in the case of work pressure, to strongly disagree and disagree indicate the absence of this dimension.

Table 1. Specifications of the dimensions of the organizational climate

\begin{tabular}{|c|c|}
\hline Dimension & Operational definition \\
\hline Autonomy & $\begin{array}{l}\text { The perception of the worker about the self-determination and responsibility } \\
\text { required in decision-making concerning work procedures, goals and priorities. }\end{array}$ \\
\hline Cohesion & $\begin{array}{l}\text { The perception of relations among the workers in the organization, the existence } \\
\text { of a friendly atmosphere of trust and proportion of material assistance in the } \\
\text { performance of tasks. }\end{array}$ \\
\hline Support & $\begin{array}{l}\text { The perception of the members on backing and tolerance in behavior in the } \\
\text { institution, this includes learning from mistakes made by the employee, without } \\
\text { any fear of retaliation from their superiors or co-workers. }\end{array}$ \\
\hline $\begin{array}{l}\text { Work } \\
\text { pressure }\end{array}$ & Feelings of tension perceived by workers caused by overwork. \\
\hline Innovation & $\begin{array}{l}\text { The perception of the courage to take risks, be creative and take on new areas of } \\
\text { work in which he has little or no experience. }\end{array}$ \\
\hline
\end{tabular}

Source: Chiang et al. (2008).

The reliability of the instrument was measured through the calculation of the Cronbach Alpha Coefficient, which reported a value of .838, which in general terms is considered acceptable (Hernández et al. 2006).

\section{Data collection and analysis}

The questionnaires were handed out to workers in sealed envelopes in the place of departure toward the drilling equipment, providing a brief explanation and emphasizing the anonymity of those who responded to the survey, in order to provide confidence and get accuracy in the answers.

\section{RESULTS}

The organizational climate was analyzed in order to establish the way how employees perceive it. For the total average of the responses, a sum of each of the replies to the questionnaire items was made. The scores obtained on the scale were examined, in the first place, through the distribution of frequencies in which there is a normal distribution with a minimum recorded value of 23 and a maximum value of 99, a kurtosis of 2.018, an average of 71 and a standard deviation of 11.18 over a general scale of 20-100 points corresponding to the sum of all responses for each question in the questionnaire. Quartiles of the distribution were identified and categories presented in Table 2 were obtained.

Table 2. Levels of acceptance of organizational climate, range of values (20-100)

\begin{tabular}{cccc}
\hline Organizational climate & Percentile & Range & $\%$ \\
\hline $\begin{array}{c}\text { Perception of unfavorable organizational climate } \\
\text { Perception of moderately favorable }\end{array}$ & 25 & Values $\leq 63$ & 25.8 \\
$\begin{array}{c}\text { organizational climate } \\
\text { Perception of favorable organizational climate }\end{array}$ & 70 & $64-72$ & 25.8 \\
$\begin{array}{c}\text { Perception of highly favorable organizational } \\
\text { climate }\end{array}$ & 100 & $73-78$ & 26.7 \\
\end{tabular}

Source: Own elaboration. 
Only the population registered below the percentile $25(25.8 \%)$ as indicated in Table 2 was considered, in order to establish a more accurate criterion for the population that is believed to perceive an unfavorable organizational climate.

The result of the descriptive statistics is presented in the Table 3 by dimensions of organizational climate.

Table 3. Statistical descriptions of the dimensions of the organizational climate

\begin{tabular}{cccccc}
\hline Dimensions & $\mathrm{N}$ & Minimum & Maximum & Average & $\begin{array}{c}\text { Standard } \\
\text { deviation }\end{array}$ \\
\hline Autonomy & 120 & 4 & 20 & 14.61 & 3.344 \\
\hline Cohesion & 120 & 4 & 20 & 15.73 & 3.193 \\
\hline Support & 120 & 4 & 20 & 15.01 & 4.174 \\
\hline Work pressure & 120 & 4 & 20 & 11.88 & 3.435 \\
\hline Innovation & 120 & 4 & 20 & 13.86 & 3.520 \\
\hline Valid N (by list) & 120 & & & &
\end{tabular}

Source: Own elaboration.

It is noted that the dimension of cohesion has the highest average (15.73), which indicates that individuals in this organization not only help and respect each other, but also support each other on work activities, and also there is a spirit of teamwork. In the same way, the dimensions of support (15.01) and autonomy (14.61) indicate a favorable organizational climate; according to the responses to items related to these factors, the employees feel they can count on the help of their boss when they need it, and also feel motivated and supported by him; they feel they can decide on the organization and the working methods as well, and also feel free to propose further activities related to the work they do. It can be inferred from the dimension of innovation (13.86) that the organizational climate is moderately favorable, the questions in this area were aimed at asking them the extent to which their boss encourages them to develop their own ideas and improve the ways of doing the activities. In addition, no work pressure was found in the subjects of study.

For the purpose of determining the existence of statistically significant differences between the dimensions of organizational climate in relation to sociodemographic variables, the ANOVA analysis of variance was used in order to analyze age, marital status, work area, category in the post, seniority in the category, employment status (temporary and stable) and seniority in the drilling department. The results are given below.

Table 4 shows the existence of a statistically significant difference in the dimension of cohesion regarding the employment status of workers in which, according to the results of the averages, those who are promoted to a higher level post perceive the organizational climate to be more favorable, whereas those in the stable post perceive it to be less favorable. 
Table 4. Comparison of the population averages of the dimensions of the organizational climate in relation to the employment status of workers

\begin{tabular}{|c|c|c|c|c|c|c|}
\hline Dimension & $\begin{array}{c}\text { Employment } \\
\text { Status }\end{array}$ & $\mathrm{N}$ & Average & $\begin{array}{l}\text { Standard } \\
\text { deviation }\end{array}$ & $\mathrm{F}$ & Sig. \\
\hline \multirow{4}{*}{ Autonomy } & Stable post & 33 & 15.48 & 3.465 & \multirow{4}{*}{1.727} & \multirow{4}{*}{0.182} \\
\hline & Promotion & 46 & 14.46 & 3.111 & & \\
\hline & Transitional & 41 & 14.07 & 3.438 & & \\
\hline & Total & 120 & 14.61 & 3.344 & & \\
\hline \multirow{4}{*}{ Cohesion } & Stable post & 33 & 14.61 & 3.691 & \multirow{4}{*}{3.32} & \multirow{4}{*}{$.040^{*}$} \\
\hline & Promotion & 46 & 16.43 & 2.934 & & \\
\hline & Transitional & 41 & 15.85 & 2.851 & & \\
\hline & Total & 120 & 15.73 & 3.193 & & \\
\hline \multirow{4}{*}{ Support } & Stable post & 33 & 14.24 & 4.63 & \multirow{4}{*}{1.849} & \multirow{4}{*}{0.162} \\
\hline & Promotion & 46 & 15.91 & 3.626 & & \\
\hline & Transitional & 41 & 14.61 & 4.277 & & \\
\hline & Total & 120 & 15.01 & 4.174 & & \\
\hline \multirow{4}{*}{$\begin{array}{l}\text { Work } \\
\text { pressure }\end{array}$} & Stable post & 33 & 12.39 & 2.999 & \multirow{4}{*}{1.849} & \multirow{4}{*}{0.162} \\
\hline & Promotion & 46 & 11.28 & 3.769 & & \\
\hline & Transitional & 41 & 12.15 & 3.351 & & \\
\hline & Total & 120 & 11.88 & 3.435 & & \\
\hline \multirow{4}{*}{ Innovation } & Stable post & 33 & 13.88 & 4.278 & \multirow{4}{*}{1.192} & \multirow{4}{*}{0.307} \\
\hline & Promotion & 46 & 14.39 & 3.187 & & \\
\hline & Transitional & 41 & 13.24 & 3.176 & & \\
\hline & Total & 120 & 13.86 & 3.52 & & \\
\hline
\end{tabular}

Note: ${ }^{*} \mathrm{p} \leq .05$ Source: Own elaboration

The existence of a statistically significant difference in the dimension of autonomy regarding the work area was determined; the average shows that maintenance workers perceive the organizational climate to be more favorable, whereas operational workers perceive it to be less favorable (Table 5).

Table 5. Comparison of the population averages of the dimensions of the organizational climate in relation to the work area

\begin{tabular}{ccccccc}
\hline Dimension & Workárea & $\mathrm{N}$ & Average & $\begin{array}{c}\text { Standard } \\
\text { deviation }\end{array}$ & F & Sig. \\
& Operation & 89 & 14.20 & 3.351 & & \\
Autonomy & Maintenance & 31 & 15.77 & 3.084 & 5.263 & $.024^{*}$ \\
& Total & 120 & 14.61 & 3.344 & & \\
\hline \multirow{3}{*}{ Cohesion } & Operation & 89 & 15.93 & 3.014 & & \\
& Maintenance & 31 & 15.16 & 3.652 & 1.345 & .248 \\
& Total & 120 & 15.73 & 3.193 & & \\
\hline
\end{tabular}




\begin{tabular}{cccccccc} 
& Operation & 89 & 14.93 & 4.374 & & \\
Support & Maintenance & 31 & 15.23 & 3.594 & .113 & .738 \\
& Total & 120 & 15.01 & 4.174 & & \\
\hline \multirow{3}{*}{ Work pressure } & Maintenance & 31 & 12.03 & 2.972 & .078 & .781 \\
& Total & 120 & 11.88 & 3.435 & & \\
\hline \multirow{3}{*}{ Innovation } & Operation & 89 & 13.97 & 3.342 & & \\
& Maintenance & 31 & 13.55 & 4.032 & .322 & .571 \\
& Total & 120 & 13.86 & 3.520 & & \\
\hline
\end{tabular}

Note: ${ }^{*} p \leq .05$ Source: Own elaboration.

The ANOVA analysis of variance reported no existence of statistically significant differences between the organizational climate and the marital status of workers, age, and category of worker, seniority in their current category, and seniority in the drilling area.

No correlations between age and the dimensions of the organizational climate were found when performing the analysis of correlation of the dimensions of the organizational climate with the worker's age, job category, and seniority in the category (Table 6). However, a weak positive correlation between the category of the worker and the time they have worked in the job category with the dimension of autonomy was identified, which means that the higher the job category and the permanence in the category, the more sense of autonomy the workers show to perform their tasks. No correlations between these demographic variables and the other dimensions of the organizational climate were found.

Table 6. Correlation of the dimensions of the organizational climate with workers' age, category, and seniority in the category

\begin{tabular}{|c|c|c|c|c|c|c|c|c|}
\hline & $\underset{<}{\infty}$ & $\begin{array}{l}0 \\
0 \\
0 \\
0 \\
0 \\
0 \\
0 \\
0\end{array}$ & 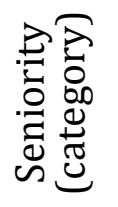 & 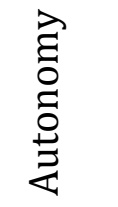 & $\begin{array}{l}\tilde{0} \\
\bar{y} \\
\frac{0}{0} \\
0\end{array}$ & 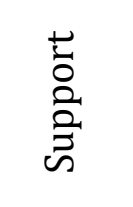 & 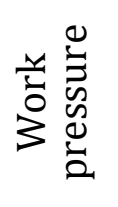 & 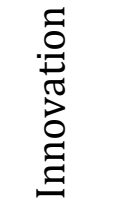 \\
\hline Age & 1 & $.214^{*}$ & $.358^{* *}$ & .131 & -.075 & -.041 & -.057 & -.027 \\
\hline Category & & 1 & -.053 & $.200^{*}$ & -.071 & -.057 & .091 & -.074 \\
\hline Seniority(category) & & & 1 & $.180^{*}$ & -.035 & -.153 & .026 & -.078 \\
\hline Autonomy & & & & 1 & .132 & .066 & $.190^{*}$ & $.204^{*}$ \\
\hline Cohesion & & & & & 1 & $.521^{* *}$ & .061 & $.503^{* *}$ \\
\hline Support & & & & & & 1 & -.030 & $.668^{* *}$ \\
\hline Work pressure & & & & & & & 1 & $.183^{*}$ \\
\hline Innovation & & & & & & & & 1 \\
\hline
\end{tabular}

*. The correlation is significant in level 0,05 .

**. The correlation is significant in level 0,01 .

Source: Own elaboration.

CONCLUSION

Organizational climate studies provide information about the perceptions of individuals in relation to the interactions among their members and the organizational processes. The results 
obtained in this research indicate a favorable organizational climate in the dimensions of cohesion, support from managers toward workers, autonomy and work pressure; moderately favorable for the dimension of innovation; the results did not report a very favorable organizational climate in the oil company involved in the present investigation, due to the fact that none of the answers were found to be in the item number 5 , which represents the absence of a very favorable working environment in the company. It is thus recommended that close attention should be paid to the maintenance and enhancement of the organizational climate.

The ANOVA analysis of variance reported no existence of statistically significant differences between the organizational climate and the marital status, age, category of worker, seniority in their current category, and seniority in the drilling area. Therefore, these variables do not influence the perception of workers about the organizational climate.

On the other hand, a statistically significant difference in the work area to which they belong and the dimension of autonomy was found, the average indicated that maintenance workers perceive the organizational climate to be more favorable, whereas operational workers perceive it to be less favorable. This result acts as a model for future qualitative research to identify the causes of this result. Also, a statistically significant difference between the employment status and the dimension of cohesion was found, in which those who are promoted to a higher level post perceive more mutual support, respect and spirit of teamwork; it is inferred that this is a logical result, since they are promoted to a higher post, but still remains open to future research in the organization. The Pearson correlation analysis reported only a weak positive correlation between the category of worker and the seniority in the job category with the dimension of autonomy; this correlation cannot be considered as relevant despite the fact that it was found, since the numbers do not indicate a correlation as such.

It was not possible to make a comparison between the results obtained in the present study and other studies, due to the fact that, in the search for publications in scientific journals, no analysis of organizational climate in Mexican oil companies was found; only studies to obtain academic degrees in countries such as Ecuador and Costa Rica were found. This research is expected to open up the possibility of conducting further research on this subject in oil companies, by virtue of the importance of the organizations of this field in the economic and social development of Mexico.

\section{References}

Alves, J. (2000). Liderazgo y clima organizacional. Revista de Psicología Del Deporte, 9 (1-2), 123-133. Retrieved from http://www.rpd-online.com/article/view/63/63

Bernal, I., Pedraza, N.A. \& Sánchez, M.L. (2015). El clima organizacional y su relación con la calidad de los servicios públicos de salud: diseño de UN modelo teórico. Estudios Gerenciales, 31, 8-19.

Brunet, L. (2011). El clima de trabajo en las organizaciones: Definiciones, diagnóstico y consecuencias. México: Trillas.

Casas, J., Repullo, J.R., Lorenzo, S. \& Cañas, J.J. (Julio, 2002). Dimensiones y medición de la calidad de vida laboral en profesionales sanitarios. Revista de administración sanitaria. VI (23), 143-160. Retrieved from http://rrhhesgc.wikispaces.com/file/view/Calidad+de+vida+laboral.pdf

Castillo, L., Lengua, C. \& Pérez, P.A. (2011). Caracterización psicométrica de UN instrumento de clima organizacional en el sector educativo universitario Colombiano. International Journal of Psychological Research, 4 , (1), 40-47. Retrieved from http://www.redalyc.org/articulo.oa?id=299022819006

Contreras, F., Barbosa, D., Juárez, A., Uribe, A.F., \& Mejía, C. (2009). Estilos de liderazgo, clima organizacional y riesgos psicosociales en entidades Del sector salud. UN estudio comparativo. Acta Colombiana de Psicología, 12 (2): $13-26$. 
Lpez, C.D.J.G., Caraveo, M.D.C.S. \& Perez, E.G.S. (2016). Organizational Climate and Oil Cmpanies. Multidimensional Study with Workers from the Drilling Departmentin Tabasco, Mexic. Archives of Business Research, 4(6), 340-350.

Chiavenato, I. (2011). Administración de recursos humanos. El capital humano en las organizaciones. (9aㅡ Ed.). México: McGrawHill.

Chiang, M.M., Salazar, C.M., \& Núñez, A. (November, 2007). Clima organizacional y satisfacción laboral en UN establecimiento de salud estatal: Hospital tipo 1. Teoría, 16 (002), 61-76. Retrieved from

file://C:/Users/Usuario/Downloads/clima_organizacional_y_satisfaccion_laboral_en_un_establesimiento_de_salu d_estatal_134_.pdf

Chiang, M.M., Salazar, C.M., Huerta, P.C. \& Núñez, A. (July, 2008). Clima organizacional y satisfacción laboral en organizaciones Del sector estatal (instituciones públicas) desarrollo, adaptación y validación de instrumentos. Revista Universum, 23(2), 66-85. Retrieved from http://www.scielo.cl/scielo.php?pid=S0718$23762008000200004 \&$ script=sci_arttext\&tlng=en

Davis, K. \& Newstrom, J.W. (2003). Comportamiento humano en el trabajo (11aㅡ Ed.). México: McGrawHill.

Downey K.H., Hellriegel D., Phelps M. \& Slocum, J.W. (July, 1974). Organizational climate and job satisfaction: a comparative analysis. Journal of Business Research, 2(3), 233-248.

Fernández, T. (July, 2004). Clima organizacional en las escuelas: UN enfoque comparativo para México y Uruguay. Revista Electrónica Iberoamericana sobre Calidad, Eficacia y Cambio en Educación, 2(2), 43-68. Retrieved from http://www.redalyc.org/articulo.oa?id=55120205

Furnham, A. (2001). Psicología organizacional. El comportamiento Del individuo en las organizaciones. México: Alfaomega.

González, J.J. \& Parra, C.O. (2008). Caracterización de la cultura organizacional, clima organizacional, motivación, liderazgo y satisfacción de las pequeñas empresas Del Valle de Sugamuxi y su incidencia en el espíritu empresarial. Pensamiento \& Gestión, 25. Retrieved from http://www.scielo.org.co/scielo.php?pid=S1657$62762008000200003 \&$ script=sci_arttext\&tlng=en

Hernández, R., Fernández, C. \& Baptista P. (2006). Metodología de la investigación. (4⿳ạ. Ed). México: McGraw Hill.

Martín, M. (2000). Clima de trabajo y organizaciones que aprenden. Educar, 27, 103-117. Retrieved from file://C:/Users/Usuario/Downloads/20736-20660-1-PB.pdf

Méndez, S., Hernández, R., \& Vargas, B.E., (July-December 2013) La relación entre el clima laboral y la cultura organizacional en el contexto Del modelo de valores en competencia. Ciencias administrativas teoría y praxis, 2 (9), 85-109.

Mújica de González, M. (May, 2007). Gestión del clima organizacional: una acción deseable en la universidad. Laurus, 13 (24), 290-304. Retrieved from http://www.redalyc.org/articulo.oa?id=76111485014

Robles-García, M., Dierssen-Sotosa, T., Martínez-Ochoa, E., Herrera-Carrala, P., Díaz-Mendib A. R. \& Llorca-Díaz, J. (2005). Variables relacionadas con la satisfacción laboral: UN estudio transversal a partir Del modelo EFQM. Gaceta Sanitaria, 19 (2). Retrieved from http://scielo.isciii.es/scielo.php?script=sci_arttext\&pid=S021391112005000200006

Salgado, J.M., Remeseiro, C. \& Iglesias, M. (1996). Clima organizacional y satisfacción laboral en una PYME. Psicothema, 8 (2), 329-335. Retrieved from http://www.redalyc.org/articulo.oa?id=72780208

Sandoval, M.C. Concepto y dimensiones Del clima organizacional. Hitos de Ciencias Económico Administrativas, (27), 78-82.

Segredo, A.M., \& Díaz, P.A. (2011). Clima organizacional en la gestión Del coordinador docente de estado en la Misión Médica Cubana. Educación Médica Superior, 25 (3), 255-274. Retrieved from http://scielo.sld.cu/scielo.php?pid=S0864-21412011000300004\&script=sci_arttext

Silva, M. (1992). Hacia una definición comprehensiva Del clima organizacional. Revista de psicología general y aplicada, 45, (4), 4443-451. Retrieved from file:///C:/Users/Usuario/Downloads/DialnetHaciaUnaDefinicionComprehensivaDelClimaOrganizacio-2378428.pdf

Walpole, R.E., Myers, R.H., Myers, S.L. \& Ye, K. (2007). Probabilidad \& Estadística (8a. Ed.). México: PEARSON Educación. 
Watkin, C. \& Hubbard, B. (2003). Leadership motivation and the drivers of share price: the business case for measuring organizational climate. Leadership and Organization Development Journal, 24(7), 380 - 386. Retrieved from group Emerald database.

Werther, W.B. \& Davis, K. (2008). Administración de recursos humanos. El capital humano en las empresas (6ª . Ed.). México: McGraw-Hill.

Wether, W.B., Davis, K., \& Guzmán, M.P. (2014). Administración de recursos humanos. Gestión del capital humano (7a. Ed.). México: McGraw-Hill. 